\title{
Bankruptcy Prediction: Evidence-based Experiences in the Banks
}

\author{
Sanaa Hasan Hilo ${ }^{1}$, Khelood A. Mkalaf ${ }^{2}$ \\ \{sanahsanhelo@gmail.com ${ }^{1}$, Hwhit27@gmail.com ${ }^{2}$ \} \\ Techniques of Materials Management, Department, Institute of Administration - Rusafa \\ Middle Technical University, Baghdad ${ }^{1}$, \\ Techniques of Materials Management Department, Technical Institute for Administration \\ Middle Technical University, Baghdad ${ }^{2}$
}

\begin{abstract}
This study aims to predict the bankruptcy of private banks by adopting Altman Z-score's model. The financial position of these banks had been classified into three zones: safe zone, gray zone, and distress zone. Five of the famous private banks were selected that achieved the research objectives. The most important result of this study is to determine the financial position of these private banks that are located in the failure zone and financial hardship area. A major suggestion is needed to apply the Altman Z-score's models to avoid and reduce financial risks. It also contributes to identifying the weaknesses and strengths of the bank's financial position. As it assists bank managers in solving these problems in time.
\end{abstract}

Keywords: Altman Z-score's model, Financial distress, Predicting failure, Financial ratios, Bankruptcy, Private banks.

\section{Introduction}

Currently, the majority of the previous studies that focus on analyzing the financial failure of companies had a traditional theoretical character. [33], [37]. Where more than 90 years ago, previous studies indicated that the majority of companies were interested in studying the prediction of financial failure to survive, grow, and continue in market competition [3], [8]. Many of the financial analysis approaches have been used [9], [10], however, the most important ones are Altman's model due to its accuracy in detecting the early bankruptcy of companies [3], [14], [35]. In the context of the prediction of financial failure at banks, frequently, the annual financial reports are the main source for evaluating the performance of banks [2], [23]. Which, it mostly depends on the data on the income statements and the balance sheet [9]. As the annual financial position gives bank management the ability to achieve its goals and the possibility of survival, growth, and competition in the labor market [31]. The global economic challenges facing banks have imposed the need to adopt realistic scientific financial analysis methods that contribute to predicting the potential risks that banks face [27], [38]. As well as, determining its financial position, whether it is within the safe zone, the area of financial hardship, it will face financial failure or bankruptcy [29].

In the UK financial crisis, Almamy et al., (2016) study has proven that the predictive power of the Z-score model was (82.9\%), which is consistent with Taffler's (1982) UK model [3]. Similarly, the importance of this model is increased with the financial crisis of the Kazakhstan 
banking system. As, it had face sharp devaluation, high level of non-performing loans, and low liquidity level accompanied by constant state support using budgetary funds to stabilize the financial system according to The National Bank of the Republic of Kazakhstan: Financial Stability Report of Kazakhstan dated 2014. The risk of this bank's bankruptcy had been estimated at $4.3 \%$ up to $8.7 \%$. But, the Kazakhstan banking system is powerfully supported by the government policy that is working to maintain of stability of the financial system in this country [13]. On the other hand, this model contributed to solving the financial crises that facing "Greece's systemic banks". For the prevention of full-scale banking collapse, it had imposed capital controls. Also, it covered the capital shortfall by attracting fresh capital from investors and shareholders. Its capital was raised by a collection of equity offerings, bong swaps, and the sales of foreign subsidiaries [24]. For this reason, this study applied Altman Z-score's model to a sample of private Iraqi banks listed on the Iraq Stock Exchange.

\section{Methodology}

In this study, Altman Z-score's model was used to predict financial failure and determine its position. Where five of the famous Iraqi private banks listed with the Iraq Stock Exchange were selected to accomplish the study objectives. Besides, these banking activities may expose it to financial risks due to the trading of stocks and financial instruments in the stock market. The data was collected by approving the financial statements of these banks for the five years between 2014-2018. Also, the income statement and balance sheet for each bank were used in the annual reports published by the Securities Commission. Figure 1 shows a summary of the Iraqi private banks selected. The data had been analyzed by using financial criteria financial ratios. Based on the quantitative statistical methods such as Pearson Coefficient, general trend. Ethics approval had been obtained for the application of this study in selected Iraqi Private Banks

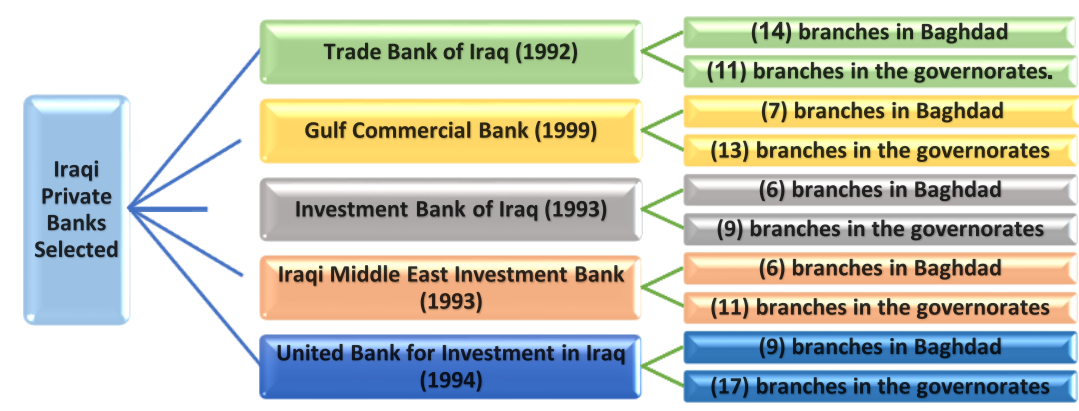

Fig. 1. Shows a summary of the Iraqi Private Banks selected.

\section{Altman Z-score's Model}

Currently, financial risk is one of the most significant problems facing local and international banks [26]. Where, majorities of banks are facing different challenges in the stock market and threats of financial speculation [9], such as decrease or increase in the price of 
financial stocks, debt defaults, profitability, liquidity, interest, tax, financial distress, the deficit in debt payments, etc.[12]. Accordingly, banks need to reduce financial risk ratios by using financial analysis methods that can help their management in determining their financial position. Besides survival, growth, and continuation of competition in the stock market [11]. For this reason, many previous studies indicated that an "AltmanZ-score's model" is one of the most common models used for financial failure analysis [8], and determining the financial position of any company based on adopting Z-score's indicators [36]. It contributes to predicting bankruptcy or predicting failure for companies by carrying out multivariate analysis with the relative importance of each factor in the discriminatory and analyzed [10]. That adopted mathematical equations to investigate the performance of companies [6], [36]. Altman has developed this model for more than 50 years [4]. The Altman model has adopted variables like "Z-score" to identify the financial failure for the companies. That had been used by the Beaver (1966) model. Then, the financial failure analysis model based on the Altman-Z-Score had a new development by Toraman and Karaca (2016) study. Their study classifies the company position into three zones concerning their calculated Z-Scores namely [6], [8]:

(1) Safe zone when $(Z>3)$ this referring there no risk of financial failure,

(2) Grey zone when $(1.81<Z<3)$ is displays as neutrality, and

(3) The distress zone when $(\mathrm{Z}<1.81)$ is referring to high risk.

In the context of prediction of financial failure for banks, this model has been used by multiple studies due to its effectiveness in determining their financial position [9]. One of the most important risks is financial bankruptcy, which it will be exposed to in the future. Due to its reliable contribution for the third parties, it also can obtain the benefiting from these results, such as bank directors, agencies, distressed companies, the banking industry, shareholders, and the main provider of financing [32]. Whereas, these entities are particularly interested in reducing the level of bad loans to maximize profitability on credit activity. Therefore, banks seek to reduce the risk of default and, on the other hand, pay attention to capital adequacy. Investors also need reliable tools to help them make the right choice for their portfolios [6], [17]. For example, Fadhilah and Kurniawati's (2018) study applied the size of liquidity ratio of working capital to total assets for evaluated bankruptcy prediction in the National Private Banks Foreign Exchange listed in the Indonesian Stock Exchange. Banks insolvent were (29\%) between 2010 - 2013. Comparing with banks that are in the gray area (71\%) in 2010 and 2013, and $(67 \%)$ in 2011 and 2012. The safe bank was (5\%). As a result, a Z-score on bankruptcy prediction for these banks appears similarly [16].

\subsection{Financial Ratios Based on the Altman Z-score's Model}

Altman Z-score's model uses the financial ratios for the income statement and the balance sheet to assess a company's liquidity, profitability, and efficiency. It can predict the financial position of a company if it is within the safety zone or risky zone [28]. Predicting financial failure or bankruptcy helps companies make the right decisions and procedures to avoid this risk [5]. Accordingly, financial ratios are among the forecasting techniques that are affected by multiple factors [27], such as financial leverage, solvency, revenues, and profitability that enable an estimate of the company's market strength [34]. Altman, (2019) study has indicated that the company's valuation depends on; Classifying the company within the database of markets that provide feedback about the current company's position in the market, evaluating the company's repayment potential through bonds, loans, and commercial papers, and development of business 
performance by using financial analysis transforms and changes in the company, which are the most vital characteristics in determining the level of the company's position. So, in this study, the Altman Z-score model had adopted to predict the financial failure of the selected banks. It can assist the administration in identifies its financial position based on an assessment of the level of potential future risk. However, in this study, only four variables were adopted to estimate the financial position of the selected banks specifically: Networking capital, percentage of earnings retained, incomes power, and market ratio.

\section{Results}

\subsection{Study Model}

Altman Z-score's model had been adopted as an efficiency measurement tool to predict the financial failure of selected banks, and to determine their current financial position within the stock market. Table (1) illustrates the model and its linear equation [6], [7], [29]. Altman Zscore's model consists of four key variables, comparing with the original model that consists of five variables. Where the fifth variable (X5) represents sales to total assets, it's usually using to measure the potential losses of industrial companies by determining the impact of the percentage of their sales in the market [30]. The results of the modified Altman model showed that the success rate for determining Z-score was $90.9 \%$. Besides, the possibility of predicting the company's bankruptcy date one year before its bankruptcy. The accuracy rate of these results was $97 \%$ [7]. So, the financial ratios adopted from the financial statements are significant in the analysis process to determine bankruptcy risks, analyze risks at the levels of operation, and perform the finance activities [32]. These include measuring profitability, liquidity, selffinancing capacity, and debt. It is often useful to find out the ability to pay interest and pay off loans [30].

Table 1. Altman Z-score's Model (1983).

\begin{tabular}{ccc}
\hline & \multicolumn{2}{c}{ Altman Z-score's Model (1983) } \\
\hline Varibles & Symbol & Z=6.56x1+3.26x2+6.72x3+1.05x4 \\
\hline Z & Z & Equation \\
X1 & WC/TA & Overall index \\
X2 & RE/TA & Working Capital/Total Assets \\
X3 & EBIT/TA & Retained Earnings /Total Assets \\
X3 & MC/TL & Earnings before Interest \& Taxes/ Total Assets \\
& Source; (Altman et.al.,2016; Anjum,2012; Manaseer \& Al-Oshaibat, 2018) \\
\hline
\end{tabular}

\subsection{Classification of Selected Banks Based on the Discrimination Zones}

The financial position for the selected Iraqi banks based on the average of the Z- Scores has described in Table 2. As it shows from the (5) private Iraqi banks that were selected, there are (4) banks located within the safe zone. Accordingly, the percentage of banks within the safe zones was (80\%), except for the Middle East Bank. As, its located in the gray area According to the average value of $(\mathrm{z})$ as it reached (1.84), which requires taking caution and caution on the 
part of the bank in the future for the possibility of financial hardship and taking measures to ensure that it becomes within the safe zone.

Table 2. Results Discrimination zones for Selected Iraq Private Banks

\begin{tabular}{lcc}
\hline Iraq Private Banks & Ave. Z- Score & Discrimination zones \\
\hline Commercial Bank of Iraq & 5.25 & "Safe" zone \\
Gulf Commercial Bank & 3.04 & "Safe" zone \\
Investment Bank of Iraq & 3.93 & "Safe" zone \\
Iraqi Middle East Investment Bank & 1.84 & "Grey" zone \\
United Bank for Investment in Iraq & 2.79 & "Safe" zone \\
\hline
\end{tabular}

The results of the trend analysis for the $\mathrm{z}$ value during the period 2014-2018 had shown in Table (3). Its shows that the financial position for each Iraqi Commercial Bank, the Gulf Commercial Bank, and the Investment Bank of Iraq are located within the safe zone and have a high value (z). Which is enhances the financial position of these banks. Whereas it indicated that the Middle East Bank has been located within the "Grey Zone" since 2015, and it has turned into financial hardship in recent years. So, it is an indication that the financial position of this bank is in danger. Which is may affect investors and the bank shares. Thus, the financial standing of this bank will be in doubt. On the other hand, the financial performance position of the United Investment Bank during the first four years had located within the safety zone. Nevertheless, it became within the financial distress zone in the last year. So, this requires the bank's management to take the needed measures to reduce the risk and correct its strategies to maintain its market value.

Table 3. Shows Z- Score for the Iraq Private Banks Selected

\begin{tabular}{|c|c|c|c|c|c|c|}
\hline \multicolumn{7}{|c|}{ Discrimination Zones of the selected Iraq Private Banks } \\
\hline Iraq Private Banks & & & Years & & & Z- Score \\
\hline & 2014 & 2015 & 2016 & 2017 & 2018 & \\
\hline Commercial Bank of Iraq & 5.20 & 5.34 & 5.37 & 5.17 & 5.17 & Safe \\
\hline Gulf Commercial Bank & 3.35 & 2.83 & 2.60 & 3.23 & 3.19 & Grey 2016 \\
\hline Investment Bank of Iraq & 4.28 & 4.12 & 4.01 & 3.74 & 3.52 & Safe \\
\hline $\begin{array}{l}\text { Iraqi Middle East } \\
\text { Investment } \text { Bank }\end{array}$ & 2.83 & 2.38 & 1.60 & 0.66 & 1.74 & $\begin{array}{c}\text { Grey } \\
\text { Distress } 2017\end{array}$ \\
\hline $\begin{array}{l}\text { United Bank for Investment in } \\
\text { Iraq }\end{array}$ & 3.83 & 3.94 & 4.09 & 3.59 & 0.00 & Distress 2018 \\
\hline
\end{tabular}

\subsection{Pearson Correlation Matrix}

Pearson correlation matrix is applied to find whether there is a significant relationship between the research variables. Also, to identify the most variable that has affected the financial performance for selected banks. As it appears in Table 4, there is a significant relationship between the measured research variables. The results have proved that there is a strong positive correlation of (0.930) between the value of $(\mathrm{z})$ and $(\mathrm{x} 1)$, which represents working capital to total assets as they reached. Also, there is a strong significant correlation (0.806) between the value of ( $\mathrm{z}$ ) and (x2), which represents retained earnings to total assets. While, there was a weak positive correlation $(0.277)$ between the value of $(z)$ and $(x 3)$, which represents earnings before 
interest and taxes to total assets. Finally, there was a strong correlation of (0.643) between the value of $(\mathrm{z})$ and $(\mathrm{x} 4)$, which represents the book value of equity to total liabilities.

Table 4. Shows the Pearson correlation matrix Results

\begin{tabular}{cccccc}
\hline \multicolumn{6}{c}{ The Results of the Pearson Correlation Matrix } \\
\hline $\mathrm{X} 1$ & 1 & $\mathrm{X} 2$ & $\mathrm{X} 3$ & $\mathrm{X} 4$ & $\mathrm{Z}$ \\
\hline $\mathrm{X} 2$ & 0.742 & 1 & & & \\
$\mathrm{X} 3$ & 0.169 & 0.251 & 1 & & \\
$\mathrm{X} 4$ & 0.680 & 0.407 & -0.081 & 1 & \\
$\mathrm{Z}$ & 0.930 & 0.806 & 0.277 & 0.643 & 1 \\
\hline
\end{tabular}

\subsection{Analysis of the Financial Ratios Based on the Altman Z-Score Model}

In this study, the final results show there were two from five banks selected has located at the Distress Zone. While the third one has been placed at the Grey Zone for many reasons as indicated below:

Net Working Capital: The results of the position financial analysis for the networking capital shown that:

- $\quad$ The United Bank for Investment in Iraq is threatened with bankruptcy during 2018 for several reasons. As it appears from Figure 2, the fixed assets have started to decline since the year 2016 , by an amount respectively were $(0.014,0.020$, and 0.026$)$. Also, the working capital adequacy was rising to $(36 \%)$ in 2018 , which is more than the minimum permissible percentage in the Iraqi banking system (12\%).

- The financial activities of the Iraqi Middle East Investment Bank for the period 20142018 indicated threatened with bankruptcy during 2017. In addition to the dispersion and instability of the financial position since 2015 for several reasons, as shows in Figure 3.

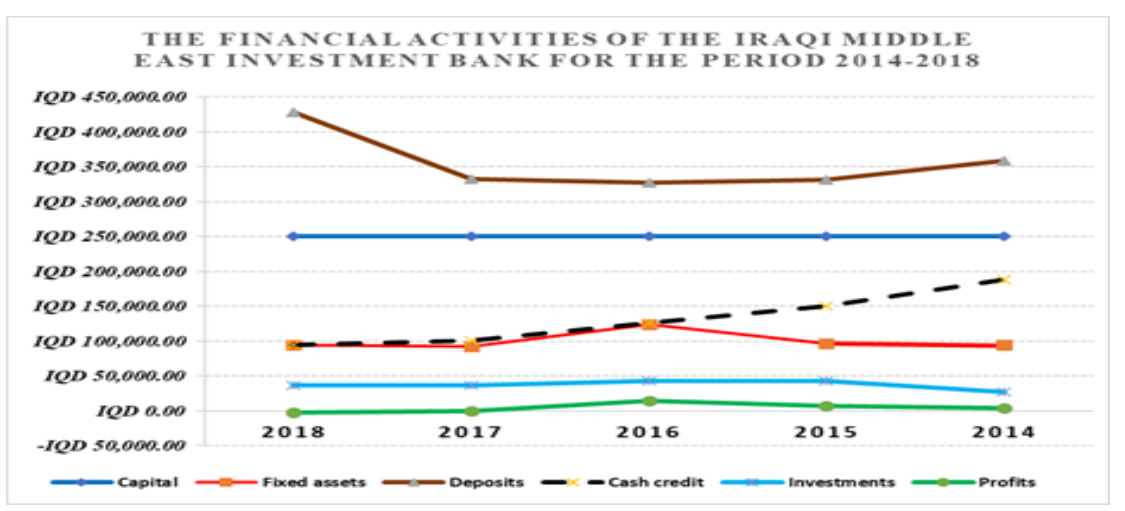

Fig. 2: The financial activities of the United Bank for Investment in Iraq for the period 2014-2018 


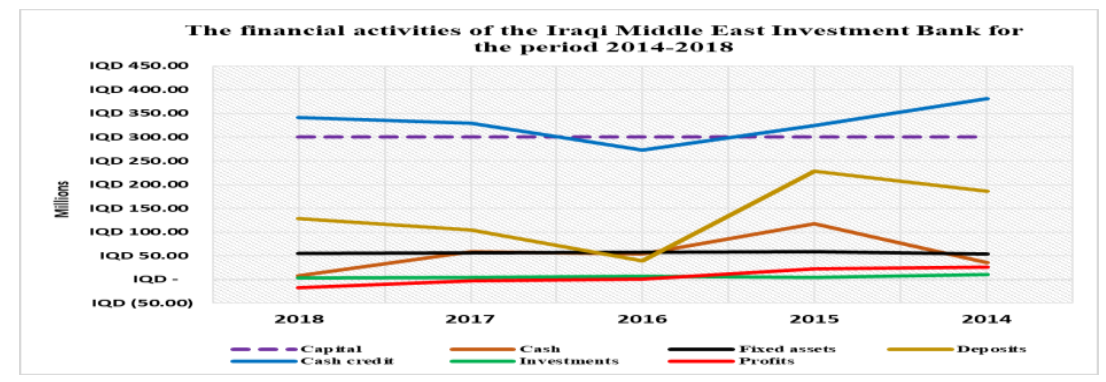

Fig. 3: The financial activities of the Iraqi Middle East Investment Bank for the period 2014-2018

As it appears from Figure 3, the fixed assets have started to decline since the years 2015, 2016, and 2018 by an amount respectively were $(0.034,0.20$, and 0.021$)$. Also, the working capital adequacy was rising to (110\%) in 2018, which is more than the minimum permissible percentage in the Iraqi banking system (12\%). That has indicated a high investment rate. That is means there is higher dispersion, higher risk ratios, and instability due to the increase and decrease in the trend of all variables due to the lack of a good strategy for management in planning and execution.

The Banks Financial Leverage: The financial leverage for the banks selected was demonstrations as following:-

- The United Bank for Investment in Iraq indicated that the percentage of earnings retained from $2014-2018$ as respectively $(-6.9 \%)$ in $2014,(1.5 \%)$ in $2015,(0.3 \%)$ in $2016,(-$ $8.5 \%)$ in 2017 , and $(2.1 \%)$ in 2018.

- The percentage of earnings for the Iraqi Middle East Investment Bank retained from 2014, 2015 , and 2016 as respectively $(1.4 \%, 2.1 \%$, and $4.8 \%)$. Then, it's started to decline to (-0.2) during 2017 and decline to (-0.9) in 2018. Consequently, the bank was unable to distribute profits to shareholders because of the loss.

Incomes Power: The results of this study confirmed the reason that lead to the bankruptcy of these banks was the weakness in achieving profits.

- The United Bank for Investment in Iraq exposed a continuing high percentage of losses in profits since 2014. The loss ratio was (0.081) in 2018, compared to (0.096) in 2017, (18.187) in 2016, (0.015) in 2015, and (0.041) in 2014.

- $\quad$ The Iraqi Middle East Investment Bank has suffered from profit inability since 2014. Earning power was increased to (0.35) in 2015 and to (0.53) in 2016. Then, it was a decline $(-0.23)$ in 2017. and (-0.71) in 2018.

Market Value: The results of the study showed that the financial leverage for these banks was as follows:

- The financial leverage ratio of The United Bank for Iraqi Investment has reached since 2014 , respectively $(59 \%)$ in $2014,(71 \%)$ in $2015,(43 \%)$ in $2016,(\% 35)$ in $2017,(42 \%)$ in 2018. As a result of the high debt ratios of the bank. 
- The financial leverage ratio of Iraqi Middle East Investment Bank has reached since 2014 , respectively $(117 \%)$ in $2014,(120 \%)$ in $2015,(116 \%)$ in $2016,(123 \%)$ in 2017 , $(164 \%)$ in 2018 . As a result of the high debt ratios of the bank.

\section{Discussion}

This study confirms the applicability of Altman Z-score's model to predict the financial failure of selected Iraqi private banks. A result of this study revealed that the performance of the Middle East Bank has continued to decline. Its financial position had located within the Grey zone during the years 2015, 2016, and 2018. Therefore, in 2017, it faced financial risk as a result of an increasing decline in its performance. Its financial position had located in the Distress zone. Although the result of the z-score shows the financial position for each of the Iraqi Commercial Bank, Iraqi Investment Bank, and Al Khaleej Commercial Bank within the safety zone area, still, they had suffered from high dispersion in financial performance and uncertainty. While the result of $\mathrm{z}$-sore has shown the performance of The United Investment Bank located within the safe zone during the early years of its works, however, It is performance dropped to be in the Distress zone in 2018. Consequently, this financial insolvency is an indication of the bankruptcy of this bank, its inability to perform its financial obligations towards shareholders and investors, and its inability to repay debts.

Bank bankruptcy or financial failure is considered a critical threat to the national economy more than business company failures due to its harmful and negative impact on other banks' systemic risk [36]. Therefore, Therefore, it must detect banking failures before it occurs to correct bank performance and avoid bankruptcy [25]. Equity investors also focus on preserving capital to obtain returns and profits. Therefore, they avoid investing in the securities of companies experiencing financial distress. It adopts strategies in selecting companies that have continuous growth in the stock market, a strong investment budget, the ability to repay debts, and the ability to generate profits [4]. Consequently, Altman Z-score's model is the most widely used technique for analyzing financial failure because it reveals early on the company's financial distress [8]. It has been used by scholars as a standard to measure credit risk in many empirical studies and practical applications [5]. Where these results of this study agree with the Manaseer \& Al-Oshaibat, (2018) study. It is confirmed the need to adopt the Altman model in predicting the financial position of banks to avoid bankruptcy and correct deviations in their financial performance in time.

\section{Conclusion}

Presently, the increasing global economic crisis has affected the performance of Iraqi private banks. The administration of these banks should review their financial policy for borrowing and interest, select the right strategy that assists to offer cash liquidity, and achieve profits and returns. In addition to taking suitable procedures to correct deviations in financial performance. So, it can contribute to avoiding risk and financial bankruptcy. The most important proposal of this study is that the Central Bank of Iraq can adopt the "Altman Z-Score model" as a control tool to measure the financial risks that will be exposed to banks in the future. Thus, it can be taking appropriate measures to correct the banking business before reaching bankruptcy. This model is considered a standard for measuring banking performance, as it contributes to identifying efficient banks with continuous growth activities in the stock market. 
Based on this, it's necessary to adopt the variables of this model in banking studies because of their importance in determining the ability of banks to operate in a business environment without reaching high risks and avoiding bankruptcy. Furthermore, applying this model to the rest of the other governmental and private Iraqi banks that have defaulted in their financial performance, to help them avoid reaching bankruptcy.

Finally, for the future researchers in this area; (1) to conduct advanced studies that include adding additional financial indicators to measure the bank's performance and the potential financial risks that may be exposed in the future. (2) to apply this model in the industrial, service, commercial, or investment sectors due to its importance in determining the competitive position of companies. As well as the possibility of their survival in the business market. (3) to expand the application of this model on larger samples to include local and international sectors.

\section{References}

[1] Abou-El-Sood H. Are regulatory capital adequacy ratios good indicators of bank failure? Evidence from US banks. International Review of Financial Analysis. 2016 Dec 1; 48: 292-302.

[2] Adeusi SO, Akeke NI, Adebisi OS, Oladunjoye O. Risk management and financial performance of banks in Nigeria. Risk Management. 2014;6(31):123-9.

[3] Almamy J, Aston J, Ngwa LN. An evaluation of Altman's Z-score using cash flow ratio to predict corporate failure amid the recent financial crisis: Evidence from the UK. Journal of Corporate Finance. 2016 Feb 1;36:278-85.

[4] Altman EI. Applications of distress prediction models: What have we learned after 50 years from the Z-score models?. International Journal of Financial Studies. 2018 Sep;6(3):70.

[5] Altman EI, Hotchkiss E, Wang W. Corporate financial distress, restructuring, and bankruptcy: analyze leveraged finance, distressed debt, and bankruptcy. John Wiley \& Sons; 2019 Mar 26.

[6] Altman EI, Iwanicz-Drozdowska M, Laitinen EK, Suvas A. Financial distress prediction in an international context: A review and empirical analysis of Altman's Z-score model. Journal of International Financial Management \& Accounting. 2017 Jun;28(2):131-71.

[7] Anjum S. Business bankruptcy prediction models: A significant study of the Altman's Z-score model. Available at SSRN 2128475. 2012 Aug 13.

[8] Apan M, Öztel A, İslamoğlu M. Comparative empirical analysis of financial failures of enterprises with altman Z-score and VIKOR methods: BIST food sector application. Australasian Accounting, Business and Finance Journal. 2018;12(1):77-101.

[9] Badea I, Matei G. The Z-Score Model for Predicting Periods of Financial Instability. Z-Score Estimation for the Banks Listed on Bucharest Stock Exchange. Finance: Challenges of the Future. 2016 Jan 1;16(18).

[10] Bandyopadhyay A. Managing Portfolio Credit Risk in Banks. Cambridge University Press; 2016 May 9.

[11] Berger AN, Klapper LF, Turk-Ariss R. Bank competition and financial stability. InHandbook of Competition in Banking and Finance 2017 Sep 29. Edward Elgar Publishing.

[12] Bitar M, Pukthuanthong K, Walker T. The effect of capital ratios on the risk, efficiency and profitability of banks: Evidence from OECD countries. Journal of international financial Markets, Institutions and Money. 2018 Mar 1;53:227-62.

[13] BOLAT A. Evaluating the current financial state of banking sector in Kazakhstan using Altman's Model, Bankometer Model. Revista Espacios. 2017 Oct 18;38(48).

[14] Chiaramonte L, Liu H, Poli F, Zhou M. How accurately can Z-score predict bank failure?. Financial markets, institutions \& instruments. 2016 Dec;25(5):333-60.

[15] Delen D, Kuzey C, Uyar A. Measuring firm performance using financial ratios: A decision tree approach. Expert systems with applications. 2013 Aug 1;40(10):3970-83.

[16] Fadhilah S, Kurniawati I. ANALISIS PREDIKSI KEPAILITAN PADA BANK UMUM SWASTA NASIONAL DEVISA YANG TERDAFTAR DI BURSA EFEK INDONESIA TAHUN 2010-2013. Jurnal REKSA: Rekayasa Keuangan, Syariah dan Audit. 2018 Jul 4;4(1):93-112. 
[17] Hardinata L, Warsito B. Bankruptcy prediction based on financial ratios using Jordan Recurrent Neural Networks: a case study in Polish companies. InJournal of Physics: Conference Series 2018 May 1 (Vol. 1025, No. 1, p. 012098). IOP Publishing.

[18] Iraqi Securities Commission: The annual financial statements of Commercial Bank of Iraq for the years 2014 to 2018.

[19] Iraqi Securities Commission: The annual financial statements of Gulf Commercial Bank for the years 2014 to 2018.

[20] Iraqi Securities Commission: The annual financial statements of the Investment Bank of Iraq for the years 2014 to 2018.

[21] Iraqi Securities Commission: The annual financial statements of the Iraqi Middle East Investment Bank for the years 2014 to 2018.

[22] Iraqi Securities Commission: The annual financial statements of United Bank for Investment for the years 2014 to 2018.

[23] Kiliç M, Kuzey C, Uyar A. The impact of ownership and board structure on Corporate Social Responsibility (CSR) reporting in the Turkish banking industry. Corporate Governance.2015 Jun 1.

[24] Kokkoris I, Anagnostopoulou M. Altman Z-Score Bankruptcy Analysis in the Greek Banking Sector. International Corporate Rescue. 2016;13(1).

[25] Le HH, Viviani JL. Predicting bank failure: An improvement by implementing a machine-learning approach to classical financial ratios. Research in International Business and Finance. 2018 Apr $1 ; 44: 16-25$.

[26] Lepetit L, Strobel F. Bank insolvency risk and Z-score measures: A refinement. Finance Research Letters. 2015 May 1;13:214-24.

[27] Liang D, Lu CC, Tsai CF, Shih GA. Financial ratios and corporate governance indicators in bankruptcy prediction: A comprehensive study. European Journal of Operational Research. $2016 \mathrm{Jul}$ 16;252(2):561-72.

[28] Lord J, Weech-Maldonado R, Davlyatov G. Predicting financial distress in nursing homes: An application of the Altman Z-Score model. Innovation in Aging. 2017 Jul;1(Suppl 1):185.

[29] Manaseer S, Al-Oshaibat SD. Validity of Altman Z-score model to predict financial failure: Evidence from Jordan. International Journal of Economics and Finance. $2018 \mathrm{Jul}$ 20;10(8).

[30] Maricica M, Georgeta V. Business failure risk analysis using financial ratios. Procedia-Social and Behavioral Sciences. 2012 Oct 24;62:728-32

[31] Mostofa M, Rezina S, Hasan M. Predicting the financial distress in the banking industry of Bangladesh: A case study on private commercial banks. Australian Academy of Accounting and Finance Review. 2016 Jan;2(1).

[32] Niresh J, Pratheepan T. The application of altman's z-score model in predicting bankruptcy: Evidence from the trading sector in sri lanka. International Journal of Business and Management. 2015 Nov $25 ; 10(12)$.

[33] North D, Baldock R, Ullah F. Funding the growth of UK technology-based small firms since the financial crash: are there breakages in the finance escalator?. Venture Capital. 2013 Jul 1;15(3):23760 .

[34] Trejo Pech CO, Noguera M, White S. Financial ratios used by equity analysts in Mexico and stock returns. Contaduría y administración. 2015 Sep;60(3):578-92.

[35] Sironi A, Resti A. Risk management and shareholders' value in banking: from risk measurement models to capital allocation policies. John Wiley \& Sons; 2007 Apr 30.

[36] Sudiyatno B, Puspitasari E. Tobin's q dan altman z-score sebagai indikator pengukuran kinerja perusahaan. Kajian Akuntansi. 2010;2(1):247233.

[37] Sun J, Li H, Huang QH, He KY. Predicting financial distress and corporate failure: A review from the state-of-the-art definitions, modeling, sampling, and featuring approaches. Knowledge-Based Systems. 2014 Feb 1;57:41-56.

[38] Verlekar RP, Kamat MS. Application and Recalibration of Altman Z-score Model for Forecasting Banking Bankruptcy in India. Wealth: International Journal of Money, Banking \& Finance. 2019 Jul $1 ; 8(2)$. 
